\title{
Eppur si muove - Risk and alternative asset classes for pension funds
}

Received (in revised form): 14th December, 2006

\section{Guy Fraser-Sampson}

is well known as both a writer and keynote speaker on investment strategy. His book Multi Asset Class Investment Strategy was published in 2006. In addition, he conducts workshops and seminars for investors around the world. He has 20 years' investment experience, including as Investment Controller with the Abu Dhabi Investment Authority. His new book Private Equity as an Asset Class will shortly be published.

Abstract The author draws attention to different investment practices between pension funds in North America and those in Europe. In particular, he points out the very different ways in which socalled 'alternative' asset classes are viewed; for example, in the UK, private equity and hedge funds combined make up only about 1 per cent of pension plan assets, whereas in North America some pension plans have allocations just to private equity of anything up to about 25 per cent.

The paper examines the example of the Yale Model in North America and suggests that it could and should be adopted by pension funds in Europe, as it is being progressively by their counterparts across the Atlantic. The author deals in turn with risk, correlation and liquidity, suggesting that the traditional risk model is no longer appropriate for modern investment approaches, and perhaps was never really valid at all. He also contends that the existing view of liquidity and solvency is mistaken, and that pension funds actually require far less liquidity than they imagine.

Pensions (2007) 12, 82-87. doi:10.1057/palgrave.pm.5950044

\section{Keywords: investment strategy, asset allocation, pension funds}

\section{Introduction}

When I lecture in Europe on portfolio theory, and particularly on Multi Asset Class investing, I usually call the session something like 'setting sail for the new world', and this is not quite as fanciful as it may at first sound. Indeed, the phrase carries two particular overtones that I think are painfully accurate. The first is that for European pension funds to move away from their traditional "what should our bond/equity mix be?' level of discussion to something which encompasses a totally new approach to investment is the equivalent of those daunting voyages into the unknown which the great renaissance explorers undertook. The second is that it is of course in the new world (well, North America

Correspondence: Guy Fraser-Sampson,

Tel: +442074359627

Email: guy@guyfs.com anyway) that Multi Asset Class investing has already become accepted as mainstream orthodoxy while it is in the old world (Europe) that it is still viewed in many quarters as dangerous heresy, akin to Galileo protesting to the Inquisition that the earth really did travel around the sun.

I can easily demonstrate the size of the gulf (for which the expanse of the Atlantic Ocean is I think an apt image) which separates the two camps. In America the Yale Endowment has at most time about two-thirds of their portfolio in the so-called alternative assets combined, somewhere around 45 per cent of which is represented by private equity and hedge funds. ${ }^{1}$ In the UK, private equity and hedge funds together represent only about one per cent of pension plan assets. ${ }^{2}$ This is indeed a startling statistic, which throws into stark relief the difference in theory and practice on each side of the pond. 
For these figures illustrate not just the dramatically different light in which the so-called 'alternatives' are held (eagerly, as a source of high returns in North America, reluctantly, and with great suspicion in Europe) but also the two different cultural outlooks on portfolio theory generally which lie behind this divergence. As I say in my recently published book, ${ }^{3}$ when we see one of the world's most respected investment gurus doing one thing, and European pension funds en masse doing precisely the opposite, and apparently on the basis that this is the correct risk-adjusted approach to take, then clearly something is fundamentally wrong. To take but three examples, there seem to be particular problems that crop up when discussion in Europe turns to matters such as correlation, liquidity and risk.

\section{Correlation}

Until the early 14th century, there was a thriving school of painters in Sienna, who turned out a succession of religious masterpieces, usually as altar pieces for churches and cathedrals. A series of disasters, however, befell Sienna shortly thereafter including a particularly virulent dose of the Black Death, and the city state was thoroughly eclipsed by nearby Florence, falling into political and economic decline. The painters, being a mercenary lot, gradually packed their bags and left for Florence in search of wealthy patrons.

The heyday of Florentine painting occurred about a century later, based around such legendary figures as Michelangelo, Brunelleschi and Ghiberti and all memorably described by Vasari, writing in about 1,550 . Why is any of this relevant to our discussion? Well, it provides a very apt example of two different schools of investment thought. You see, in the interval shared by the decline of Siennese art and the rise of Florentine art someone discovered perspective (Brunelleschi usually gets the credit, although it had earlier been experimented with by Donatello). In other words, if you go to Sienna you will see paintings that are flat and two-dimensional, whereas by the time of Michelangelo in Florence painters had recognised that just as the real world was three dimensional, so they could give expression to this in their pictures.

The two-dimensional view of finance that underpins the "what should our bond/equity mix be?' school of thought assumes that there is a fixed and inviolable relationship between 'risk' (we will examine below the problems with defining or calculating this) and reward. In other words, if you have a low-risk portfolio, say consisting entirely of bonds, and you add into it some higher risk assets such as equities then your portfolio as a whole will travel upwards and to the right along a diagonal straight line.

In fact, this does not happen in practice, at least, not automatically, and the reason is of course that the world of finance, like the real world, is three dimensional, the third dimension being correlation. In practice, so long as the higher risk assets that you add to the mix have little correlation with the existing portfolio then what will actually happen is that the line will bend upwards and to the left before curving round to parallel the previous line. In other words, as we all learned at business school, it is possible to extend the efficient frontier, or, in plain English, to construct an alternative portfolio for which one may earn a higher level of reward for the same level of risk.

The good news is that in theory it is possible to repeat this process an infinite number of times, thus endlessly increasing your investment returns. The bad news is that in practice this does not work, since two things get in the way. First, you will very shortly start to run out of assets, which both offer a higher rate of return than your existing portfolio and demonstrate sufficiently little correlation with it. Second, even if this did not happen, you would get to a stage where the allocations that you were making to each asset class were too small to be able to make any significant difference to the return of the overall portfolio.

\section{The Yale model}

There is nothing particularly revolutionary about any of this. Markowitz and Sharpe were 
expounding their ideas decades ago. It is thus strange, to say the least, that most European pension funds see diversification not as a good thing, which can both lower risk and raise returns, but as a bad thing. Not so David Swensen, the Chief Investment Officer of the Yale Endowment, whose model is clearly based on the above theory, not least its two practical limitations, since he deals in just four or five asset classes and makes sure that his allocation to any one of them is large enough for it to make a meaningful difference to the whole (at different times he has suggested a minimum of either 10 or 15 per cent).

Does it work? It certainly does. Since 1996 the Yale Endowment has quadrupled in value (bear in mind that this period encompasses the nuclear winter of quoted equities when massive funding deficits appeared in UK occupational pension plans), and it has ranked consistently in the top percentile of US investment performance. Given such dramatic out-performance, which has been well publicised, it is therefore somewhat troubling that many European pension funds appear still never to have heard of the Yale Model and certainly not a single one, so far as I am aware, has tried to implement it.

\section{Liquidity}

One of the main reasons (excuses?) given for not deploying the Yale Model is that it leads to a very significant loss of liquidity within the portfolio. Yale is typically only about 35 per cent liquid, compared to about 94 per cent within the average UK pension plan. Sadly, this points up yet another basic misunderstanding by European pension funds. As Swensen points out, liquidity is not a good thing to be sought out, but a bad thing to be avoided wherever possible. Liquidity comes at a high price in the shape of lower returns, and sophisticated investors seek out higher returns in less liquid markets such as private equity and property.

European pension funds, on the other hand, seem obsessed with what as long ago as 1936 Keynes was already calling 'the fetish of liquidity'. ${ }^{4}$ The need for liquidity, although irrational and illusory, acts as a siren call, luring them onto the rocks of mistaken dogma. This betrays a lack of understanding of what a pension fund is, and how it functions.

A pension fund is a long-term stream of cash flows stretching into the future; in fact, in the case of a DB scheme that is still open to new members (such as a UK local authority fund) the stream of cashflows stretches out to infinity, becoming ever more unpredictable as it does so. There are those who argue that for this reason a pension fund is like a bond. This is false, for various reasons. To give but one, no bond has ever been issued the terms of which may be altered unilaterally by either party, yet this is exactly what may happen in the case of an employee-sponsored pension plan. Ironically, given the way in which the asset class has been largely ignored by European pension schemes, a pension fund in fact most closely resembles a private equity fund. Like such a fund, a pension plan is also is also a stream of cashflows. Like such a fund, it may only be validly analysed financially by resorting to compound return measures (typically IRRs).

Yet all this is peripheral to our discussion. Liquidity has to have a purpose. A need for liquidity must be driven by some real-world concern that liquidity is thought to address. The only concern for which liquidity can validly be of relevance is of course solvency. If there is no concern over a fund's solvency, then the liquidity or otherwise of its investments becomes irrelevant. Yet when does a pension fund become insolvent?

A pension fund becomes insolvent on the first date when it is unable to meet a liability (benefits payment) when it falls due. In the case of even the worst funded pension scheme in Europe, this is unlikely to happen within the next 20 years. Thus European pension schemes do not have a short-term solvency problem - so why do they need liquidity?

What European pension funds do have is a long-term investment returns problem and this is why their obsession with liquidity has such a tragic outcome, for what they fail to realise, as Swensen points out in his book, ${ }^{5}$ is that liquidity comes at a very heavy price in the 
form of lower returns. In brief, liquidity is a bad thing to be avoided, not a good thing to be sought out.

'Managers willing to accept illiquidity achieve a significant edge in seeking high risk-adjusted returns. Because market players routinely overpay for liquidity, serious investors benefit by avoiding overpriced liquid securities and locating bargains in less widely followed, less liquid market segments'.

Hence Swensen's willingness to embrace large allocations to such asset classes as private equity, property and hedge funds. The flip side is of course the almost total unwillingness of European pension funds to do the same. It is this which leads me to point out that we are presented with the bizarre spectacle of the world's leading institutional investment guru doing one thing, and European pension funds en masse doing exactly the opposite, apparently on the advice of their consultants that this is the correct course of action to pursue. This is a binary situation: either they are wrong and Swensen is right, or vice versa. There is no third alternative. (I cunningly planted a clue to the correct answer above: the value of the Yale Endowment has quadrupled since 1996.)

\section{Risk}

After liquidity concerns, 'risk' is the reason most often cited as an excuse for not investing in the so-called 'alternative' assets. Here there are two problems. First, there is a fundamental misunderstanding between consultants and trustees as to what constitutes 'risk' and thus trustees by definition cannot be making informed decisions. Secondly, the view of risk, which consultants have in mind, is simply not appropriate for the modern investment needs of long-term institutional investors.

When a lay pension trustee is told that an investment is 'high risk', they are naturally going to apply the sense in which that word is understood in its everyday context, that is, 'if you make this investment it is likely that you will lose some or all of your money'. The sense in which it is being used by the consultant is, however, 'the historic returns of this investment exhibit a high degree of volatility relative to those of the market portfolio of which it forms part'. This anomaly is never resolved, because the consultant is never asked what they mean, and neither do they take the trouble to volunteer the information. Thus, the consultant is transmitting on one wavelength while the trustee is receiving on another.

As for the risk model itself this is inherently flawed. First, it assumes that risk and volatility are one and the same; worse, it assumes that not only are they the same but that there must be some direct and unbreakable link between levels of volatility and levelsof likely return. Secondly, it is useless for modern investment purposes since it can accommodate only periodic (ie annual) returns, whereas for some asset classes, most notably private equity, periodic returns are not a valid performance measure. Incidentally, this same defect renders it unsuitable for investors such as pension funds who could and should be taking a long-term investment view, perhaps over a rolling 30-year period, rather than a short-term view from one year to another.

There are all sorts of other problems with the traditional model. It assumes that any given investment will carry the same degree of risk to any investor, whereas in fact risk will be relative according to the specific circumstances of any individual investor. One who has a target return of ten per cent and a time horizon of 20 years will obviously view an investment differently to one who has 30 per cent target and a three-year time horizon. It claims to calculate all the risk inherent in an investment that it is material and necessary for any investor to know. It assumes that all investors are rational, that all have equal information and that all markets are perfect. In fact, even arithmetically it doesn't hold water; the larger a proportion of your portfolio that any individual asset represents, the lower will be its calculated 'risk' - exactly the opposite of the instinctive (and correct) view any real life investor would take.

Thus, we encounter the absurd situation of investors such as pension funds failing to invest in the various so-called 'alternative' asset classes ('socalled' since many pension industry observers now 
believe that they could and should form the main core of many portfolios, just as they do for Yale) because they cannot calculate a 'risk-adjusted' rate of return. Accepted wisdom seems to be 'I cannot invest in private equity (to take an obvious example) because I cannot accommodate it within my risk model' rather than the more logical 'I need to invest for higher returns, therefore I need to invest in private equity; since my risk model cannot accommodate private equity returns, I need a new risk model'.

What is required in creating this new view of risk? It's prime requirement is that it should enable a pension fund to compare the returns of different asset classes validly and directly against one another. It should also, however, recognise that the risk of any one investment will be different according to the particular circumstances of any individual investor. It needs to measure that risk which is material (ie relevant to that individual investor's circumstances, in the sense of something that would make a difference to their decision process). Finally, for a pension fund it needs to recognise that investment is a very long-term process (I am aware of at least one pension fund that models its likely cashflows 100 years ahead). Fortunately, all of these various requirements can be quite easily satisfied.

Firstly, the returns of all asset classes can be restated on a vintage year basis, that is, showing the compound return earned to date from investing in that year. This means that apples can now be compared with apples. Then, mean variance analysis can be used to calculate the probability of any asset class failing to meet any given target rate of return. It is, of course, the case that many investors now use mean variance in risk analysis but none as yet employ compound returns for the exercise rather than periodic returns. It is this latter development that is key, since without it no valid comparisons can be made; in the case of private equity, for example, periodic returns are not a valid measurement of performance.

Simple phi calculations can be used to calculate the probability of any asset class returning less than any given rate of return over a long period.
Of course, this exercise can even be carried out with the rate of return set at zero in order to calculate what the long-term capital risk of any asset class may be. Incidentally, this exercise can throw up results that some may find surprising. For example, when measured for my recent book, private equity showed a capital risk of 3.4 per cent on an unweighted basis and just 0.2 per cent on a weighted basis, while total return on the S\&P 100 index (ie including dividend yield) showed about 4 per cent and effectively zero, respectively. In other words, the expectation that the consistently higher returns earned by private equity must necessarily be accompanied by higher rates of return (as the traditional risk model would require and as the vast majority of pension funds believe) is quite simply wrong.

The 'weighted' basis referred to above describes a situation where compound returns earned over a long period are given a greater weighting than those earned over a short period. I submit that this represents nothing more than simple common sense. If we are trying to ascertain how likely it is that an asset class will achieve a particular return over time, then we are clearly going to give greater credence to a compound return that has been achieved over 20 years than the one which has been earned over just one year.

\section{Towards a new world of pension investment}

Thus, we have demonstrated that the two main perceived stumbling blocks to multi-asset class investing by pension funds are misconceived. Indeed, one can go further. In understanding exactly how and why they are misconceived, one learns new techniques and approaches that are in fact extremely liberating and free one up to approach the whole business of pension fund investing in a completely new way.

Freedom from the fetish of liquidity means that one can set asset allocation levels as they were meant to be set, by reference to the target investment return of the fund, and by selection from the widest possible universe of available choices. If this seems natural and intuitive that is because it is. If one needs to invest for high 
returns and certain assets classes have delivered consistently high returns, then any artificial restriction on investing in them should be subjected to the most rigorous scrutiny, rather than being tamely accepted automatically as it seems to be today.

Freedom from the tyranny of the traditional risk model means that risk can be assessed having regard to the particular circumstances of any individual investor, and in particular to their target rate of return and their investment time horizon, rather than assuming that one size fits all. By challenging the assumption that risk and volatility are the same thing, and that there is a direct and unbreakable connection between volatility and return, one is free to measure the one and only thing that should matter to any individual investor: what is the probability of any asset class achieving over time their target rate of return?

All of this, of course, assumes that a pension fund will have measured its target rate of return on some scientific basis (ie other than the artificial net present value type basis which is commonly adopted for financial accounting purposes) and this is at present a very large assumption. Indeed, not one of the many European pension funds to whom I spoke over a period of more than two years while researching my book had done so. There were very many (almost all of them) who did not even realise that the net present value being used by their sponsor was not (and never could be) any true picture of their real liabilities. It is, of course, around this fundamental misunderstanding that the so-called Liability Driven Investment industry has grown up in Europe, surely one of the most unethical businesses in history with cynical finance professionals playing on the lack of knowledge of pension trustees. I hope it will be obvious that if you do not know what your real liabilities are then any attempt to match an artificial net present value against any portfolio, particularly one composed largely or entirely of bonds, can never be a valid exercise.
Interestingly, I believe that the phrase 'Liability Driven Investment' is being used differently by North American pension funds. There, they are attempting to model their actual future cashflows in much the way that I advocate in my book, and work out what their target rate of return needs to be to match these. This is much closer to my understanding of a true 'liability-driven' approach but to my mind still leaves the twin threats of inflation and adverse demographic change insufficiently provided for.

I have used the word 'liberating' very deliberately since what we are describing here is nothing less than the experience of realising that much of what one has been taught over the years is really no better than religious dogma with no firm logical foundation at all, and that one is completely able to explore and adopt anything one likes, provided that it is rational and matches one's own particular needs. At the risk of getting carried away, it is the financial equivalent of the Reformation, or the collapse of the communist system. Basic beliefs that have been taken for granted seemingly for ever are suddenly and completely discredited and people are left bewildered and wondering what to put in their place.

This process, however, does not happen overnight and meantime the bonfires of the Inquisition still burn, as I am sure reaction to this paper will prove. It is largely with this in mind that I have decided to adopt as its title what Galileo is reputed to have murmured as he was led away after recanting in order to avoid a heretic's death. Loosely translated, it means that the earth really does move around the sun.

\section{References}

1 Yale Endowment annual reports, various years.

2 WM Annual Survey (2005).

3 Fraser-Sampson, G. (2006) 'Multi asset class investment strategy', John Wiley \& Son Ltd, London.

4 Keynes, J. M. (1960) 'The General Theory of Employment, Interest and Money', currently Palgrave Macmillan, London.

5 Swensen, David (2000) 'Pioneering Portfolio Management', The Free Press, New York. 